\title{
複数測位信号によるマルチパス検知と 高精度測位時の精度に関する研究
}

\author{
池田 隆博1・佐田 達典2 \\ 1正会員 日本大学助手 理工学部交通システム工学科（テ274-8501 千葉県船橋市習志野台7-24-1） \\ E-mail:ikeda.takahiro@nihon-u.ac.jp \\ 2正会員 日本大学教授 理工学部交通システム工学科（†274-8501 千葉県船橋市習志野台7-24-1） \\ E-mail:sada@trpt.cst.nihon-u.ac.jp
}

\begin{abstract}
衛星測位システムは, QZSSやGalileo等の測位衛星に加え, 既存のGPSについてもL2C等の新たな民生信 号の運用など利用可能な衛星電波が増加しつつある. 衛星電波の増加により, 従来よりも良質な観測デー 夕の取得が期待されるが，これらの効果を測位に生かすには，マルチパス等の誤差を含む衛星電波の除去 が重要となる。本研究では, 筆者らが提案したマルチパス検知手法にGPSのL2C, GLONASSのL1P信号を 加え, 実際の観測データからマルチパスを含む衛星電波を検知可能か検証した。 その結果, マルチパスの 影響を含む衛星電波の検知が従来の測位信号と同様に可能であること, マルチパス検知時の指標を新たに 追加し衛星選択を行うことでFix解の取得割合が増加し測位精度が向上する場合が確認された。
\end{abstract}

Key Words : GPS, GLONASS, Multipath, Carrier Phase, Signal Strength

\section{1. はじめに}

近年，衛星測位システムは，日本の測位衛星である 準天頂衛星（QZSS : Quasi-Zenith Satellite System）の運用や EUが運用するGalileoの打ち上げ等により増加傾向にある. また，既存の衛星測位システムであるGPS（Global Positioning System）についても，従来の測位信号であるL1C/A， L2P(Y)に加え，新たな民生信号であるL2Cを搭載した測 位衛星の運用など，近代化が進みつつある

利用可能な衛星系が増加した場合, 衛星電波が遮蔽 されやすい都市部や山間部でも測位に必要な衛星数が確 保できる確率が上昇し, 従来のGPSとGLONASS（Global Navigation Satellite System）を用いた場合よりも測位可能な 箇所が増加する可能性が挙げられる. また，新たな測位 信号が利用可能となることで, 従来よりも信号強度の高 い測位信号が利用可能となり，地物によるの反射波の影 響の低減が期待される。しかしながら，衛星測位におい てこれらの効果を生かすには，マルチパス等の測位誤差 を含む衛星電波をなるべく測位計算に使用しないことが 重要となる.今後, 複数測位信号を用いた衛星測位では, このマルチパスの影響を考慮した測位計算が必要になる ものと想定される.

マルチパスの影響を受ける衛星電波を削減および検 知する方法としては, 既に他の著者から報告が行われて
おり，GNSS受信機内部の相関器幅を工夫した技術2334), 衛星電波の信号強度の特性を用いた方法5), マルチパス の影響を受けた際の搬送波位相の推移を用いた方法につ いて述べられている67. また，筆者らも信号強度に加え 搬送波位相の変化量を用いた手法について報告しており， 衛星電波選択による高精度測位時の測位率向上について 述べている8 。信号強度と搬送波位相については，GNSS 受信機から得られる観測值であるため, 受信可能な測位 信号が増加した場合，従来の測位信号と組合せることで マルチパスの影響を受ける衛星電波の検知率が向上する 可能性がある.

本研究では，GPSの測位信号であるL1C/A， L2P(Y), L2C，GLONASSの測位信号であるL1C/A，L1P，L2Pに着 目し，複数測位信号を用いた場合のマルチパス検知効果 について検証を行った. 本稿では，測位信号別に算出し たマルチパス検知指標を用いて条件別に基線解析を実施 し，測位結果に含まれるFix解の取得割合からマルチパ ス検知効果の検証を行った. また, 条件別の基線解析結 果から精度評価を行ったのでその結果を報告する.

\section{2. マルチパスの影響を受ける衛星電波の検知}

マルチパスの影響を受ける衛星電波は, 図-1に示すよ 


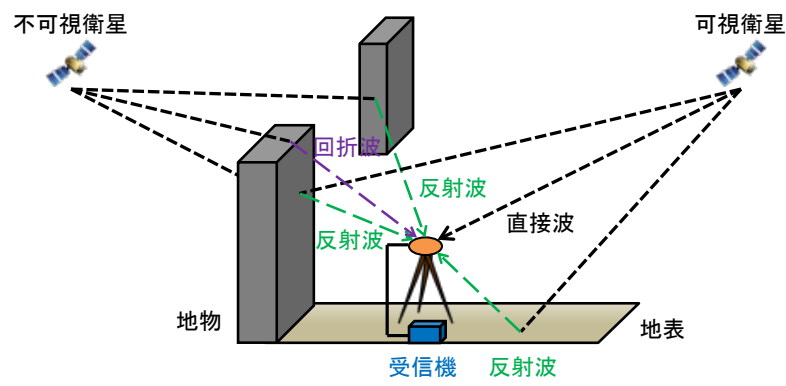

図-1＼cjkstart回折波と反射波による伝搬経路の概要

うに遮蔽物からの回り込みにより受信する回折波，遮蔽 物と地物からの反射により受信する反射波の2種類が考 えられる. どちらも直接波に対して伝搬経路の増加, 遮 蔽物の電気的な特性による信号強度の減衰が生じるため, 得られる衛星電波の観測データは直接波と比較し異なる 結果が得られるものと想定される. よって本研究では, マルチパスの影響を受ける衛星電波の検知に, GNSS受 信機から得られる信号強度 (Carier to Noise Ratio: 搬送波 電力雑音比）と搬送波位相を用いて行うものとする゙9.

まず，回折の影響を受ける衛星電波の検知には，信号 強度の特性を示寸単一ナイフエッジ回折のモデルを適用 する. 衛星と受信アンテナ間の見通し線付近に遮蔽物が ある場合，(1)式に示寸回折パラメータがー $0.7 \leq v$ とな る際, 衛星電波の回折損 $J(v)(\mathrm{dBHz})$ は(2)式で近似さ れる ${ }^{10)}$.

$v \equiv h \sqrt{\frac{2}{\lambda}\left(\frac{1}{d_{1}}+\frac{1}{d_{2}}\right)}$

$J(v)=6.9+20 \log \left(\sqrt{(v-0.1)^{2}+1}+v-1\right)$

$v:$ 回折パラメータ

$h:$ 見通し線と遮蔽物先端との距離（m)

$\lambda$ : 衛星電波波長 $(\mathrm{m})$

$d_{1}:$ 衛星と遮蔽物先端との距離 $(\mathrm{m})$

$d_{2}:$ 受信アンテナと遮蔽物先端との距離 $(\mathrm{m})$

ここで，hは遮蔽物先端が見通し線以下となる場合を 負とし，見通し線と遮蔽物先端が交わる場合， $h$ は $0 \mathrm{~m}$ と なる. $h=0$ のとき, 衛星電波波長に関わらず回折損 $J(v)$ は約 $6 \mathrm{dBHz}$ となり, $h>0$ の場合, 回折損はさらに 大きくなるため, 信号強度により回折波の影響を確認寸 ることができるものと考えられる.

次に, 反射の影響を受ける衛星電波の検知については, 搬送波の位相変化量の特性からマルチパス検知に有効な 指標の算出を行う. 衛星系に関わらず送信される衛星電 波については, 信号強度, 搬送波周波数の異なる 2 種類 以上を送信しており, 電離層遅延, マルチパスによる影

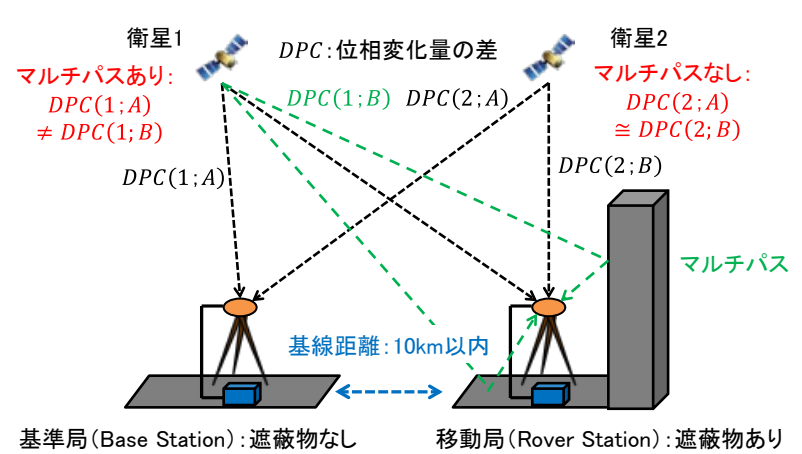

図-2 位相変化量の差 $(D P C)$ によるマルチパス検知

響を受ける場合，各々で異なる傾向が生じる ${ }^{11}$. 搬送波 位相の変化量については，位相差に正確な光速を乗じ， 搬送波に応じた周波数で割ることで距離データとして得 られるため ${ }^{12)}$, 同衛星から送信される2種類の搬送波間 の位相変化量の差 (Difference of Phase Change : 以下DPC) は(3)式で求められる。

$D P C=\left|\left(\emptyset_{t}^{L 1}-\emptyset_{t-1}^{L 1}\right) \frac{c}{f_{L 1}}-\left(\emptyset_{t}^{L 2}-\emptyset_{t-1}^{L 2}\right) \frac{c}{f_{L 2}}\right|$

$\varnothing:$ 位相積算值 (cycle) $t:$ 時刻 (s)

$L 1$ : 第1周波数 $L 2:$ 第2周波数

$c$ : 光速 $(\mathrm{c}=299792458 \mathrm{~m} / \mathrm{s})(\mathrm{m} / \mathrm{s})$

$f$ : 搬送波周波数 $(\mathrm{Hz})$

(3)式で得られるDPCには，1周波と2周波の双方の電 波で生じた電離層遅延，マルチパスによる誤差が含まれ る.しかし，電離層遅延が影響する基線長は $10 \mathrm{~km}$ 以上 の長距離基線が目安であるため, 近距離基線であれば, 影響を無視できるものと期待されるす。 よって, 基線長 $10 \mathrm{~km}$ 以内となる受信機間で得られた観測值からDPCを 求めると, マルチパスによる誤差が含まれなければ双方 で類似した結果が得られるものと想定される。

位相変化量の差を用いたマルチパス検知では，図-2に 示すように, 観測点周囲に遮蔽物がない基準局から得ら れた観測值と，観測位置に設置した移動局から得られた 観測值からDPCを算出し，(4)式に示すように基準局側 のDPCを基準值として, 位相変化量の差の較差 (Double Difference of Phase Change : 以下 $D D P C$ ）を求めるものとす る.

$D D P C=D P C_{R S}-D P C_{B S}$

$D P C_{R S}$ : 移動局で得られた位相変化量の差 $(\mathrm{m})$ $D P C_{B S}$ : 基準局で得られた位相変化量の差 (m)

また，先ほど示した信号強度によるマルチパス検知に ついても同様に，(5)式に示すように基準局側の信号強 度を基準值として，信号強度の差（Difference of Signal 
Strength : 以下DSS）を求めるものとする.

$D S S=S S_{R S}-S S_{B S}$

$S S_{R S}$ : 移動局で得られた信号強度 $(\mathrm{dBHz})$

$S S_{B S}$ : 基準局で得られた信号強度 $(\mathrm{dBHz})$

このDSS, DDPC を本研究におけるマルチパスの影響 を受ける衛星電波を検知する指標として使用するものと する.

\section{3. 測位信号別によるマルチパス検知指標の検証}

\section{(1) 検証概要}

$D S S$ とDPCによるマルチパス検知指標について, GPSのL2C，GLONASSのL1P信号を用いた場合，マルチ パス検知が可能か検証を行った．筆者らは既に，GPSの L1C/AとL2P(Y), GLONASSのL1C/AとL2Pによる組合せに ついて，回折によるマルチパスを主体的に受ける場合の $D S S$ とDPCの推移について検証を行っており，DSSに

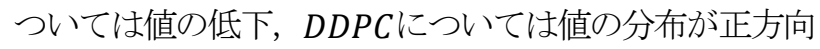
に大きくなることを確認している．本検証では，GPSの L1C/AとL2C，GLONASSのL1PとL2Pでそれぞれ指標值を 算出し, 従来の測位信号で得られる結果との比較を行っ た. 各測位信号の概要を表-1に示す.

\section{（2）検証方法}

GPSとGLONASSの各測位信号の観測データ取得につ いては，図-3に示す日本大学理工学部船橋キャンパス内 に設置した遮蔽環境の異なる7点の観測点上にGNSS受信 機を設置して実施し，観測点A0を基準局，観測点B2 B7 を移動局として同時間帯による同時測位を実施した（図 -4）. 使用した受信機は，基準局，移動局ともに二コ ン・トリンブル社製Trimble NetR8であり，データ取得は RINEX3.0形式で間隔は1Hzとした。実験日時については， 2011年11月19日，20日，22日の10:00 16:30の時間帯で, 基準局と各移動局との同時測位を3時間実施した．観測 点B2 B7の実験スケジュールを表-2に示す.

検証方法としては，基準局と移動局の同時間帯の観測 值より $D S S$ とDPCの算出を行い，遮蔽物によりマルチ パスの影響を受ける衛星電波について, 各々の指標の傾 向の確認を行った. なお, 衛星の可視性については, 観 測衛星の軌道歴より求めた仰角と方位角, 各観測点上で 事前に取得した地上型3Dレーザースキャナによる点群 データより得られた遮蔽物の仰角と真北を $0^{\circ}$ とする方 向角で行った. 点群データの取得日は，2012年2月3日で あり，観測点B2 B7に機器を設置して周囲の地物と樹木 の3次元モデルを作成した（図-5）。
表-1 本検証で用いる測位信号と周波数 ${ }^{12)}$

\begin{tabular}{|c|c|c|c|}
\hline 衛星 & 測位信号 & 周波数 $(\mathrm{MHz})$ & 用途 \\
\hline \multirow{3}{*}{$\mathrm{GPS}$} & $\mathrm{L} 1 \mathrm{C} / \mathrm{A}$ & 1575.42 & 民生 \\
\cline { 2 - 2 } & $\mathrm{L} 2 \mathrm{P}(\mathrm{Y})$ & \multirow{2}{*}{1227.60} & 軍用 \\
\cline { 2 - 2 } & $\mathrm{L} 2 \mathrm{C}$ & & 民生 \\
\hline \multirow{3}{*}{ GLONASS } & $\mathrm{L} 1 \mathrm{C} / \mathrm{A}$ & \multirow{2}{*}{$1602.0+\mathrm{k} * 0.5625$} & 民生 \\
\cline { 2 - 2 } & $\mathrm{L} 1 \mathrm{P}$ & & 軍用 \\
\cline { 2 - 2 } & $\mathrm{L} 2 \mathrm{P}$ & $1246.0+\mathrm{k} * 0.4375$ & 軍用 \\
\hline
\end{tabular}

$\mathrm{k}$ : チャンネル番号 $=-7 \sim+13$

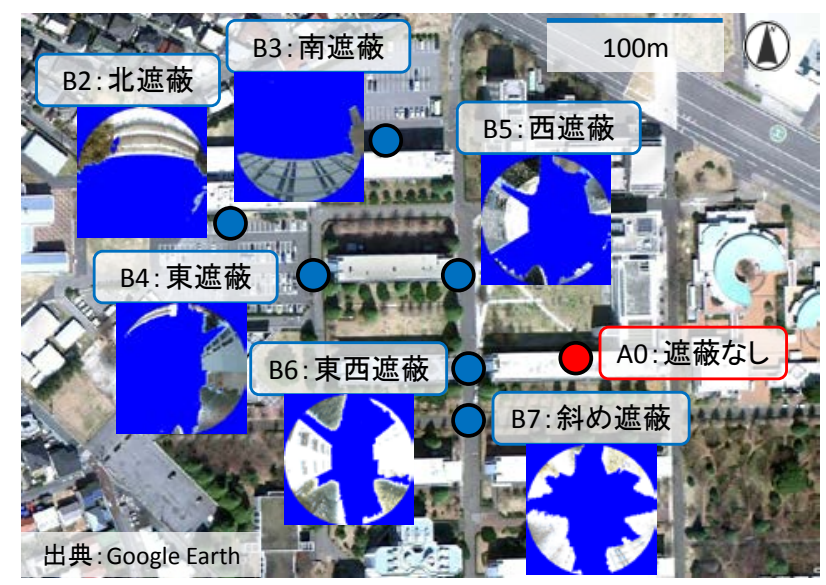

図-3 観測データの取得位置と周囲の遮蔽状況

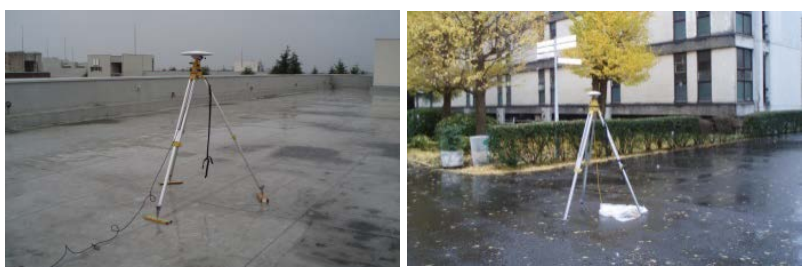

図-4 実験状況 (左 : 観測点A0 右 : 観測点B7)

表-2＼cjkstart観測点B2 B7における実験スケジュール

\begin{tabular}{|c|c|c|}
\hline 実験日 & 時間帯 & 観測点 \\
\hline \multirow{2}{*}{ 2011年11月19日 } & $10: 10 \sim 13: 05$ & B7 \\
\cline { 2 - 3 } & $13: 30 \sim 16: 30$ & B6 \\
\hline \multirow{2}{*}{2011 年11月20日 } & $10: 10 \sim 13: 05$ & B2 \\
\cline { 2 - 3 } & $13: 30 \sim 16: 30$ & B5 \\
\hline \multirow{2}{*}{ 2011年11月22日 } & $10: 00 \sim 13: 00$ & B3 \\
\cline { 2 - 3 } & $13: 30 \sim 16: 30$ & B4 \\
\hline
\end{tabular}

\section{(3) 検証結果}

$D S S$ とDDPCによるマルチパス検知指標の検証につい て，本稿では，GPSのL2C信号を送信する衛星について， 可視条件の変化が見られた観測点B2，B7について行う ものとする.

まず，図-6に示す観測点B2で観測された衛星番号01番 のGPS衛星と衛星番号24番のGLONASS衛星を対象にDSS とDDPCの算出結果を示す. 図-7より, GPSから送信さ れる各測位信号のDSSの推移を確認すると，衛星の仰 角が $60^{\circ}$ 以上となる0:00 1:10の時間帯では，測位信号に 関わらず約 $0 \mathrm{dBHz}$ で推移する傾向が見られる。また, 1:10 1:30の時間帯において可視条件が変化する際のDSS 


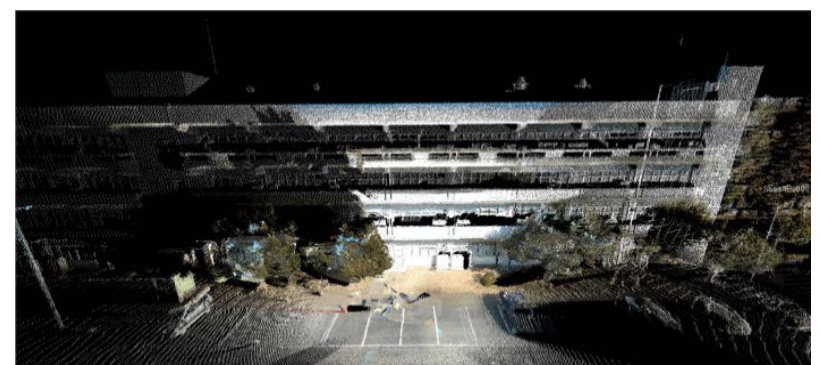

図-5３次元点群データによる地物のモデル化（観測点B2）

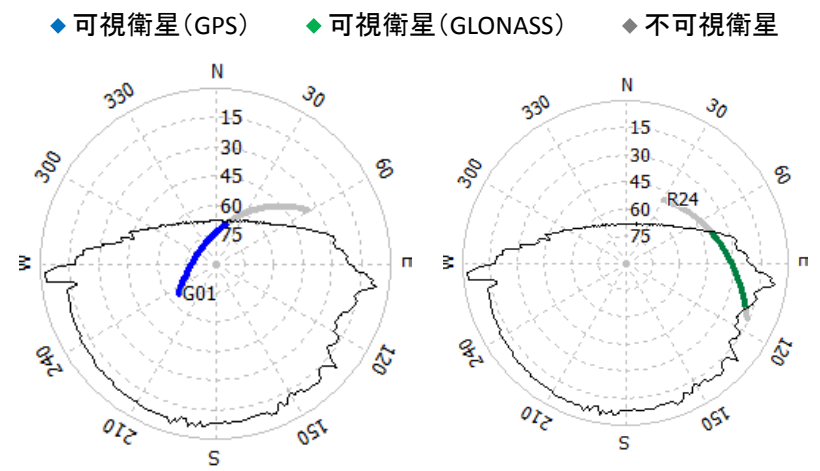

図-6 観測点B2における衛星軌道と遮蔽物位置

の推移を確認すると，L1C/A，L2Cでは-5dBHz -6dBHzの 範囲内となり, 単一ナイフエッジ回折のモデルから得ら れる6dBHzの回折損と同様の傾向を示すことがわかる. 一方, L2P(Y)のDSSの推移については, 可視条件が変化 する際のDSS の推移は-9dBHz -10dBHzの範囲内となり， 折モデルから得られる $6 \mathrm{dBHz}$ の回折損よりも大きくなる 傾向が確認された. 不可視衛星からの衛星電波は, 回折 による電波に加え，地物からの反射による電波との合成 となるため, 受信電波の位相によって信号強度の増幅ま たは減衰が生じる．L2P(Y)の信号強度の傾向については, L1C/A，L2Cと比較し移動局側の信号強度の減衰が大き く生じた可能性が考えられる.

次に, GPSの測位信号から得られたDDPCの検証結果 を図-8に示す．まず，衛星が可視時となる時間帯につい ては，どちらも0mmを中心に分布する傾向が確認でき， 基準局と移動局で得られたDPCが類似の傾向を示して いることがわかる. また，不可視時の場合， DDPCの分 布は正方向に推移する傾向が確認でき, 移動局側の $D P C$ が大きくなることがわかる．なお，L2Cの組合せに よるDDPCでは, L2P(Y)の組合せと比較し分布範囲が狭 くなるが，これは，回折波に対する地物からの反射波と の合成がL2P(Y)よりも小さかった可能性が考えられる.

GPS と同様にGLONASSから送信される各測位信号の $D S S$ とDPCCの傾向を確認する. 図-9より，DSSの推移 を確認すると, 衛星が可視時となる時間帯では, GPSと 同様に測位信号に関わらず約0dBHzで推移する傾向が見 られる. また，可視条件が変化する際のDSSの推移を確 認すると，こちらも測位信号に関わらず約-5dBHzで推移
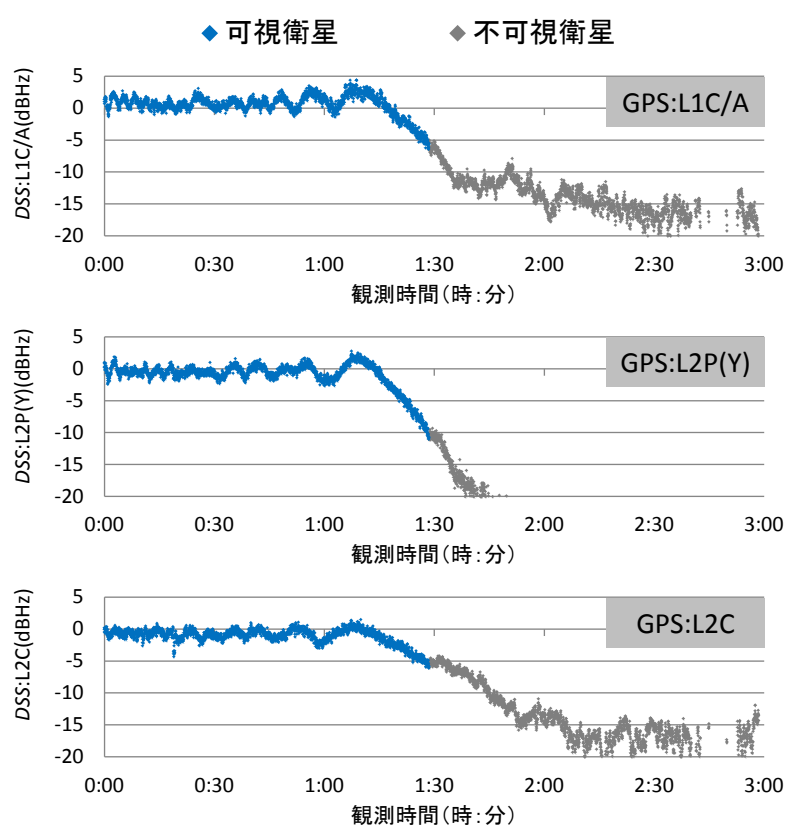

図-7 GPSにおけるDSSの検証結果（観測点B2）
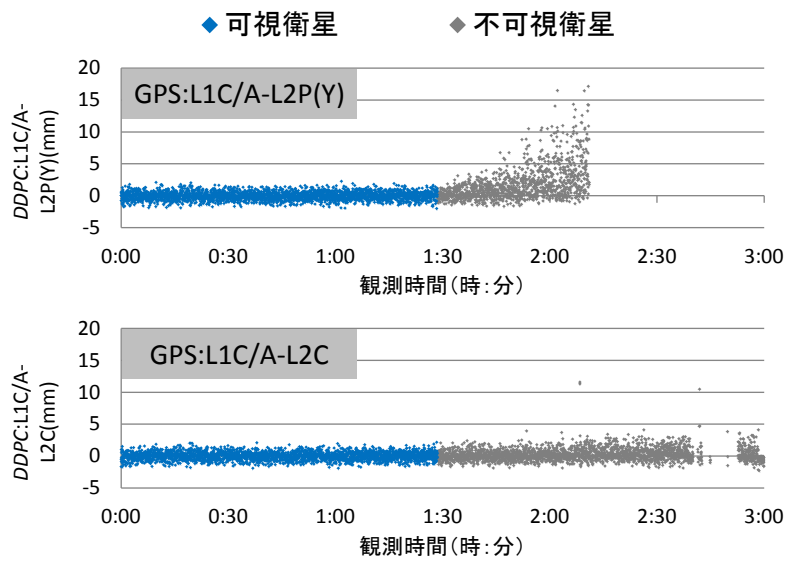

図-8ＧPSにおけるDDPCの検証結果（観測点B2）
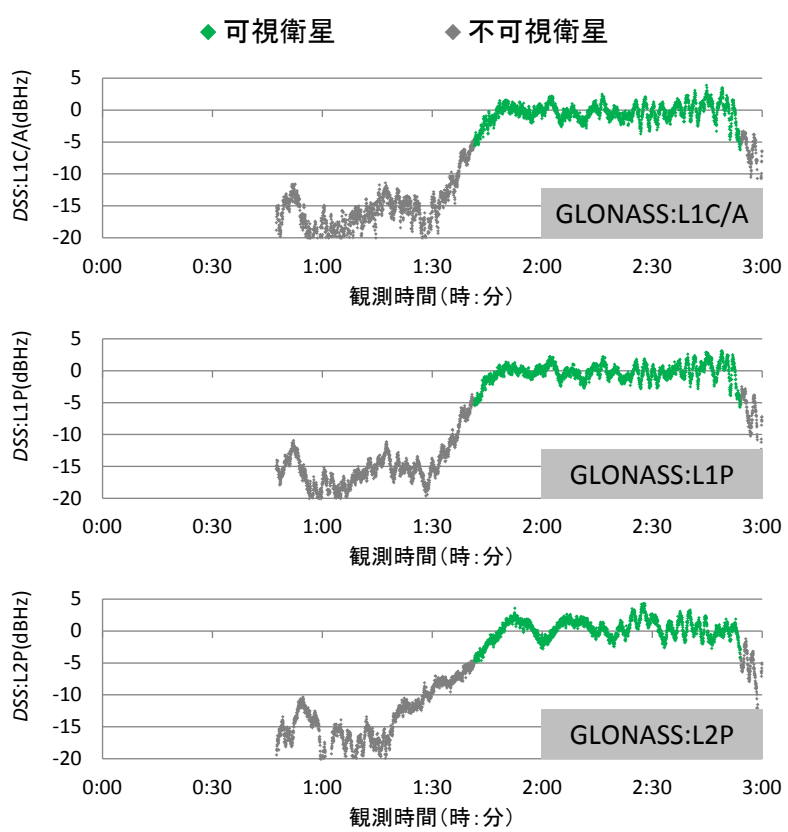

図-9ＧLONASSにおけるDSSの検証結果（観測点B2） 

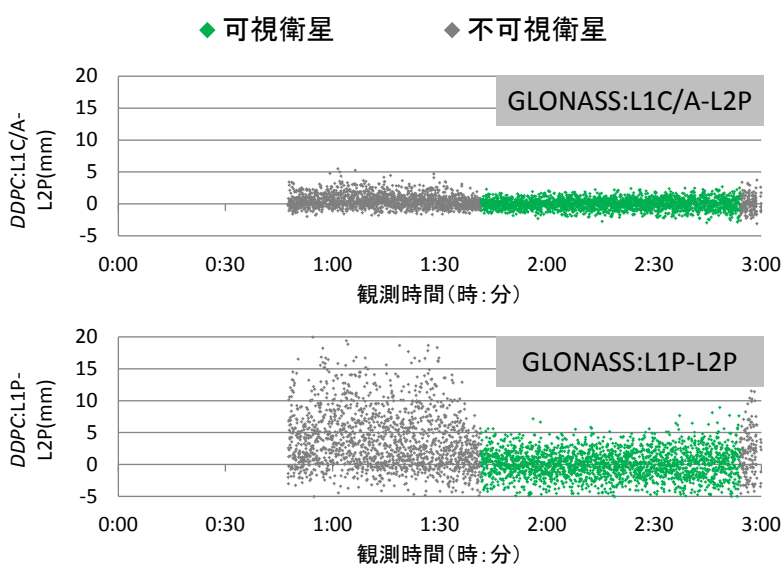

図-10 GLONASSにおけるDDPCの検証結果（観測点B2）

する傾向が見られ，GPSによるL1C/A，L2Cと同様に， 回折モデルによる回折損と同様の傾向が見られた.

次に, GLONASSの測位信号から得られたDDPCの検 証結果を図-10に示す．まず，衛星が可視時となる時間 帯について確認すると, GPS と同様に0mmを中心に分布 する傾向が見られた，L1Pの組合せによるDDPC は， L1C/Aの組合せよりも分布が大きくなる傾向が見られる が，これはL1Pで得られる位相差が，L1C/Aと比較し大 きいため, DDPCの分布範囲が広くなったものと考えら れる. 不可視時となる時間帯については, GPSと同様に 正方向に $D D P C$ が分布する傾向が確認でき，L1P-L2Pの 組合せのほうが，L1C/A-L2Pの場合よりも分布範囲が広 くなる傾向が見られた.

これらの検討結果より，衛星が不可視となり回折によ るマルチパスの影響を主体的に受ける場合，測位信号に 関わらずDSSは值の低下が確認された，GPSのL2P(Y)を 除き, 可視条件が変化する場合のDSSは-5dBHz - $6 \mathrm{dBHz}$ の範囲内となることから, 回折モデルから得られる $6 \mathrm{dBHz}$ の回折損を閾值とすることで，回折の影響を受け る衛星電波の検知は可能であるといえる. 一方, $D D P C$ については，可視時と不可視時で異なる傾向が確認でき， $D S S$ と同様に回折の影響を受ける衛星電波の検知は可能 であると考えられる．また， DDPC算出に用いる值が位 相差であるため，伝搬経路が回折波と同様に直接波と異 なる反射波についても検知が可能になるものと考えられ る.

なお，観測点B2で得られた結果を基に，他の観測点 でも同様の結果が得られるか比較を行った。 図-11に示 寸観測点B7て観測された衛星番号17番のGPS衛星と衛星 番号01番のGLONASS衛星を対象にDSS とDDPCの算出 を行った．図-12より，GPSの測位信号におけるDSSの推 移を確認すると，可視時となる時間帯では測位信号に関 わらず約 $0 \mathrm{dBHz}$ と観測点B2 2 同様の傾向が見られるが， 衛星可視条件が不可視から可視状態に推移寸る際のDSS の值も約 $0 \mathrm{dBHz}$ となり, 可視時の時間帯とほとんど差が

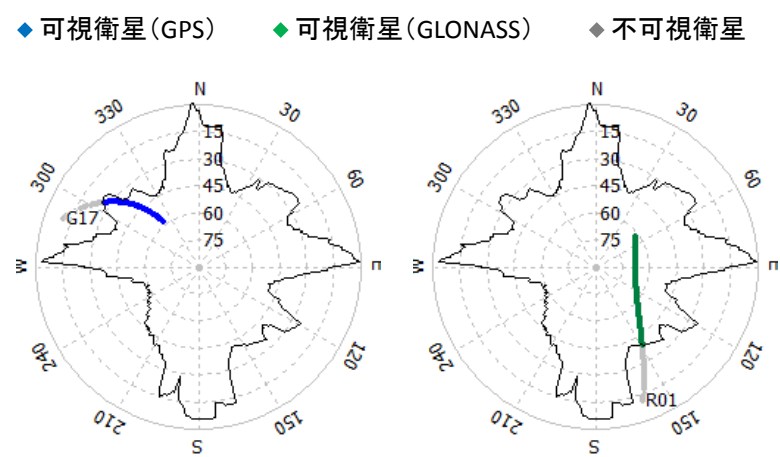

図-11 観測点B7における衛星軌道と遮蔽物位置
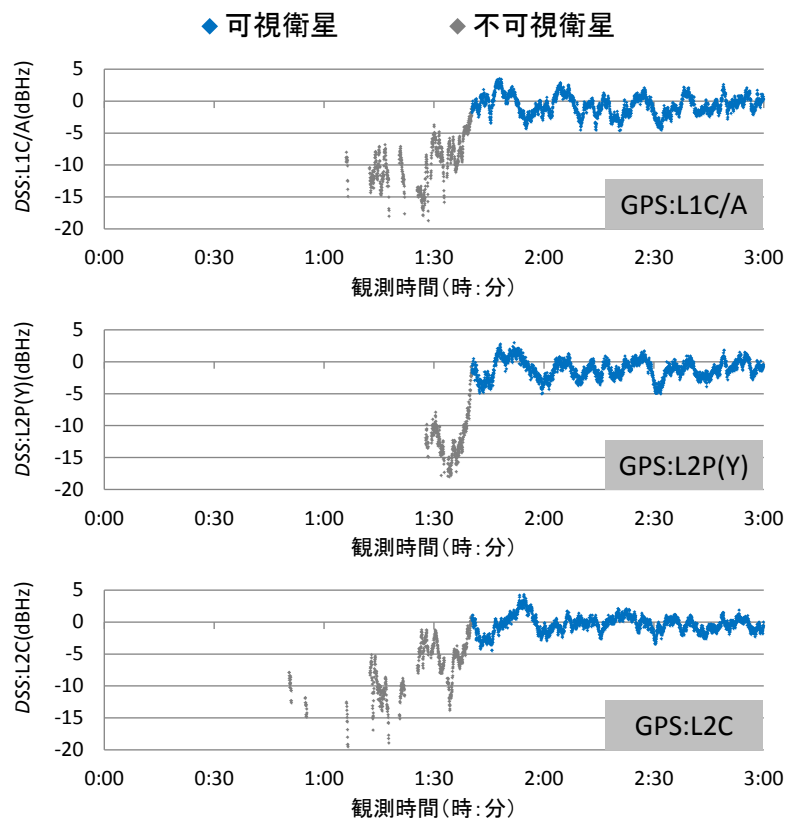

図-12 GPSにおけるDSSの検証結果（観測点B7）

見られなかった．このときの電波遮蔽物となる地物の種 類について確認を行うと，観測点B2ではコンクリート 製の建物であるのに対して，観測点B7では針葉樹であ るため，衛星可視条件の変化前後では直接波を主体的 に受信できていた可能性が考えられる. 次に，DDPCの 検証結果について確認すると，図-13より衛星が可視時 となる時間帯については，測位信号の組合せに関わらず 0mmを中心に分布する傾向が見られ，観測点B2 と同様 の結果が得られた. 不可視時の推移についても, 正方向 にDDPCが分布する傾向が確認でき，また，L1C/A-L2C の組合せのほうがL1C/A-L2P(Y)よりもDDPCの分布範囲 が狭くなる同様の傾向が確認された，GLONASSについ ては，図-14よりDSSの推移について，衛星が可視時で は約0dBHzで推移し，衛星が不可視から可視状態に推移 する際は約-5dBHzと観測点B2で得られた結果（図-9）と 同様の結果が得られた. DDPCの推移についても，可視 時では $0 \mathrm{~mm}$ 中心とした分布，不可視時では正方向に $D D P C$ が分布する傾向が観測点 $\mathrm{B} 2 て ゙$ 得られた結果と同様 に得られた（図-15）。なお，本検証で示したDSS と 

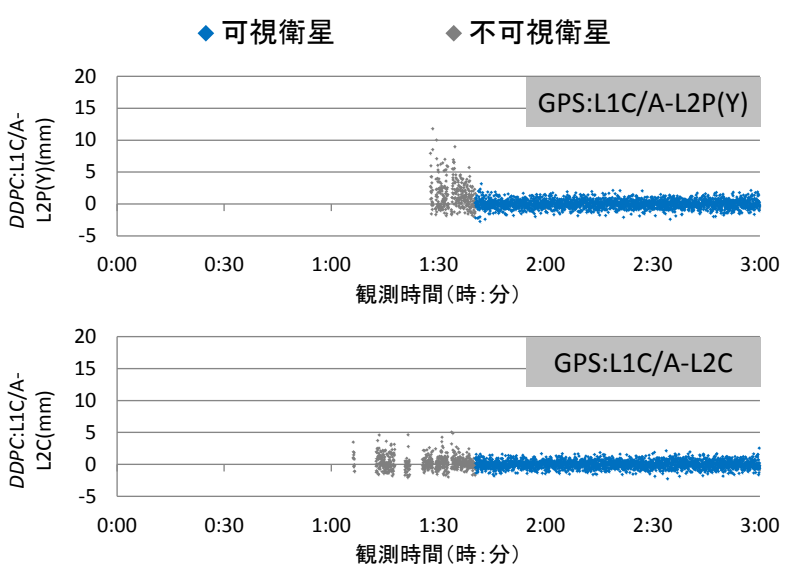

図-13ＧPSにおけるDDPCの検証結果（観測点B7）
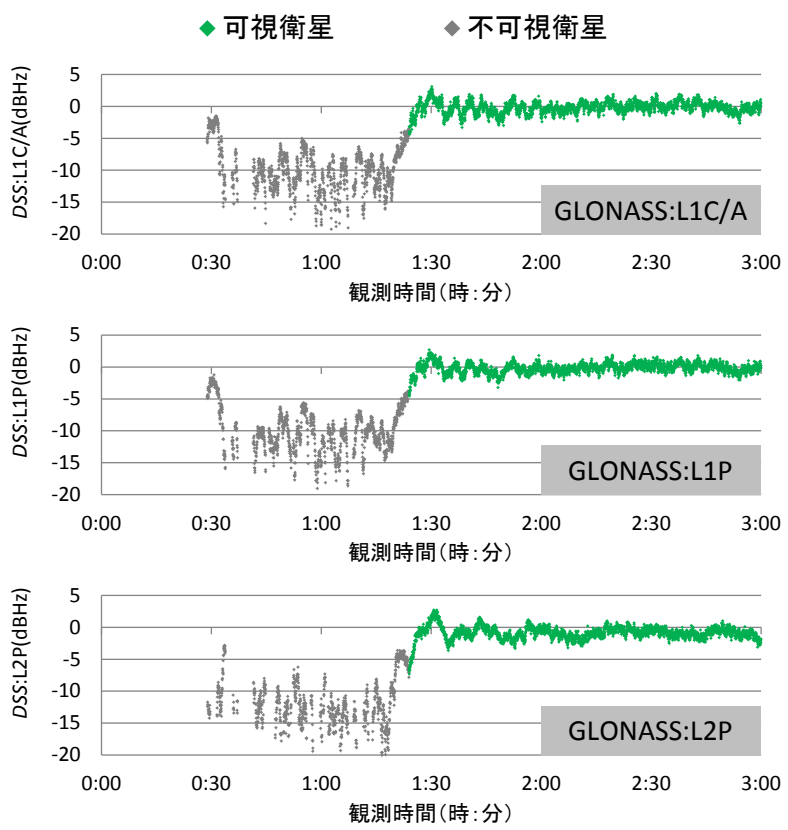

図-14 GLONASSにおけるDSSの検証結果（観測点B7）
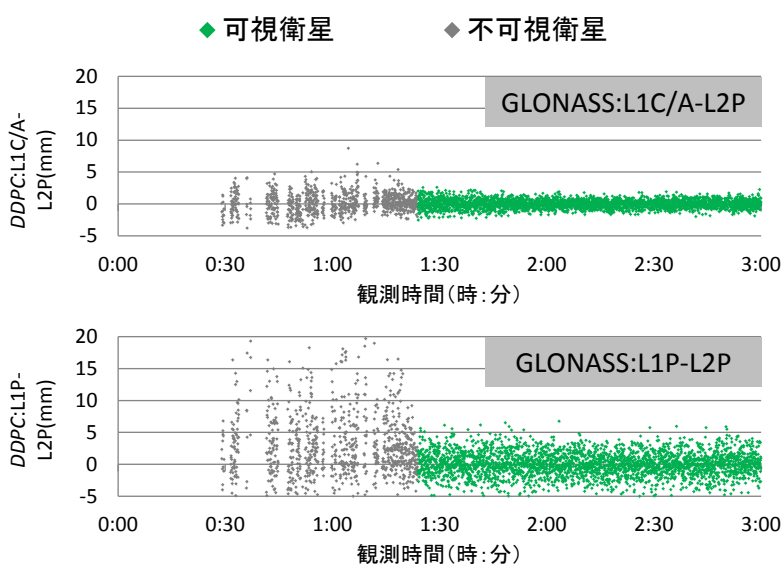

図-15 GLONASSにおけるDDPCの検証結果（観測点B7）

DDPCによるマルチパス検知指標の推移は，他の観測時 間，衛星においても同様の結果が確認された.

\section{4. 複数信号によるマルチパス検知効果の検証}

\section{(1) 検証概要}

基線解析による高精度測位において，DSS とDDPCに よる複数の検知指標を用いて衛星選択を実施し, 測位結 果に含まれるFix解の取得割合および測位精度の改善効 果について検証を行った.

\section{(2) 検証方法}

検証は，前章において観測点A0と観測点B2，B3，B7 による同時測位で得られた観測データを使用し，DSS と $D D P C$ の算出結果を参考に利用衛星を選択し,

「GPS+GLONASS」の衛星条件でキネマティック解析を 行った.

まず，DSSについては，先ほどの検証結果より衛星の 可視条件が変化する際の值は-5dBHz -6dBHzの範囲内で 推移する傾向が確認されており，理論モデルによる算出 結果とほぼ一致することがわかる．よって，DSSの算出 結果より選択する衛星の基淮は，測位信号に関わらず， (5)式より得られる值がDSS $>-6 \mathrm{dBHz}$ となる衛星を選 択するものとし，GPSではL1C/A，L2P(Y)，L2C， GLONASSではL1C/A，L1P，L2Pで得られるDSS值が対 象となる.

次にDDPCについては, 回折によるマルチパスの影響 を主体的に受ける場合，測位信号の組合せによって分布 範囲は異なるが，正方向に值が分布する傾向が確認され ており，可視時における $0 \mathrm{~mm}$ を心とする分布とは異な ることがわかる．よって，DDPCの算出結果より選択す る衛星の基準は, 測位信号の組合せ別に(4)式より得ら れる值について，60データ毎のDDPCの移動平均值を求 めて分布の中心位置を算出し，組合せ毎に表-3に示寸閾 値の範囲内となる衛星を選択するものとした．測位信号 の組合せについては，GPSではL1C/A-L2P(Y)，L1C/A-L2C, GLONASSではL1C/A-L2P，L1P-L2Pとなる．なお，これ らの值は，天頂付近が方位に関わらず開けている観測点 B7の仰角 $60^{\circ}$ 以上に飛来寸る衛星の移動平均 $D D P C$ の推 移により算出した。

衛星選択時の比較条件としては, 本検証では3条件を 設定した．条件1では「全観測衛星使用」，条件2では

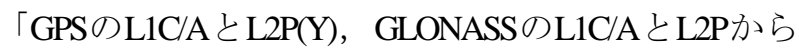
$D S S$ とDDPCを算出し，各指標で設定した閾值内となる 衛星の夕を使用」, 条件3では「前述の条件にGPSのL2C, GLONASS のL1Pを加えた全測位信号に対してDSS と $D D P C$ を算出し，各指標で設定した閾值内となる衛星の みを使用」とした．条件に従い，算出した各測位信号の $D S S$ とDPCによる指標值について，設定した閾値の範 囲外となる時間帯の衛星をRINEX3.0形式による観測デー タから除去した。 
表-3 測位信号の組合せ別による $D D P C$ の䦔値 (単位 : $\mathrm{mm}$ )

\begin{tabular}{|l|c|}
\hline GPS:L1C/A-L2P(Y) & \pm 0.30 \\
\hline GPS:L1C/A-L2C & \pm 0.25 \\
\hline GLONASS:L1C/A-L2P & \pm 0.30 \\
\hline GLONASS:L1P-L2P & \pm 0.90 \\
\hline
\end{tabular}

解析については，RTKLIB version2.4.2を使用し，基準局 側のデータは観測点A0で得られた值を使用した。一方, 移動局側のデータについては，観測点B2，B3，B7で得 られた值を使用して基線解析を実施した．解析時の設定 条件としては，バイアス決定手法をGLONASSを併用し たInstantaneous（瞬時整数バイアス決定を行う）に設定し， 仰角マスクを $15^{\circ}$ ，使用する周波数帯をL1+L2とした。 また，基準局の座標值については，近傍の電子基準点の 観測データを基準としたスタティック解析により求めた 值を使用した。基準局座標算出に使用した受信機はニコ ン・トリンブル社製Trimble 5700システムであり，実施日 時は，2011年2月3日の11:00 13:00である.

\section{(3) 検証結果}

図-16に，10分間毎（600データ）に観測時間を区切り 時間帯別に得られた衛星選択条件別のFix解の割合を示 す. なお，Fix解の判断は，キネマティック解析で得ら れたNMEA-0183フォーマットで記される解のフラグと移 動局となる観測点の基準座標值から水平方向で $20 \mathrm{~mm}$ 以 内に分布する解であるかによって行った，また，基準座 標值については，2011年6月18日の10:00 13:00に観測点A0 を基準とするスタティック解析により得られた值を使用 した。基準座標值の取得に使用した受信機は，ニコン・ トリンブル社製Trimble5700システムである.

衛星選択条件別に算出結果を比較すると，全観測衛 星使用時では，観測点B2，B7においてFix解の取得割合 は0\%となる傾向が見られ，Fix解が全く得られない時間 帯が確認された。一方，衛星選択時では，観測点B3の 2:40 3:00の時間帯を除き，Fix解の取得割合が向上し，マ ルチパスの影響を受ける衛星電波を解析から除去するこ とで継続した高精度測位が可能であることがわかる。ま た，観測点別に条件2と条件3の結果について比較を行う と，観測点B2では，衛星の選定条件が媛しい条件3のほ うが，条件2よりもFix解の所得割合が約10\%低下する時 間帯が見られ，一方，観測点B3では差はほとんど見ら れず，観測点B7では，Fix解の取得割合が5\% 10\%増加す る傾向が見られた.

図-17に，衛星選択条件別における解析時の衛星数の 推移を示す。まず，観測点B2について条件別に推移を 確認すると，衛星選択時にFix解が100\%とならない時間 帯では，衛星数が5機以下となる場合が確認でき，GPS とGLONASSを併用したキネマティック解析に必要な衛 星数が得られていないことがわかる.この傾向は，観測
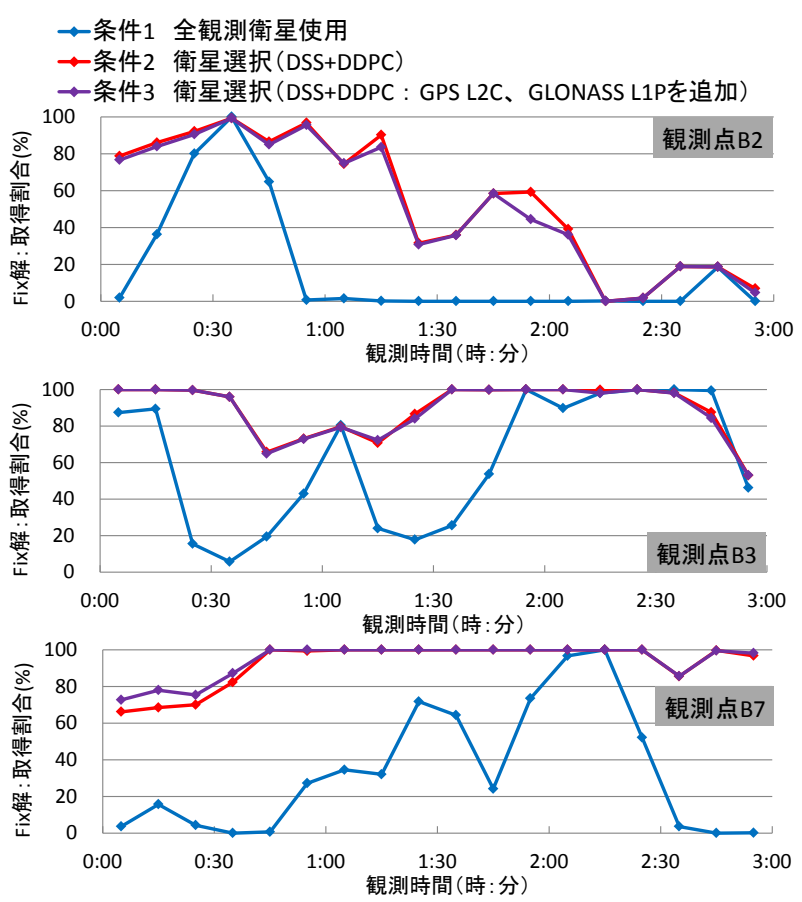

図-16 観測時間帯別によるFix解の取得割合
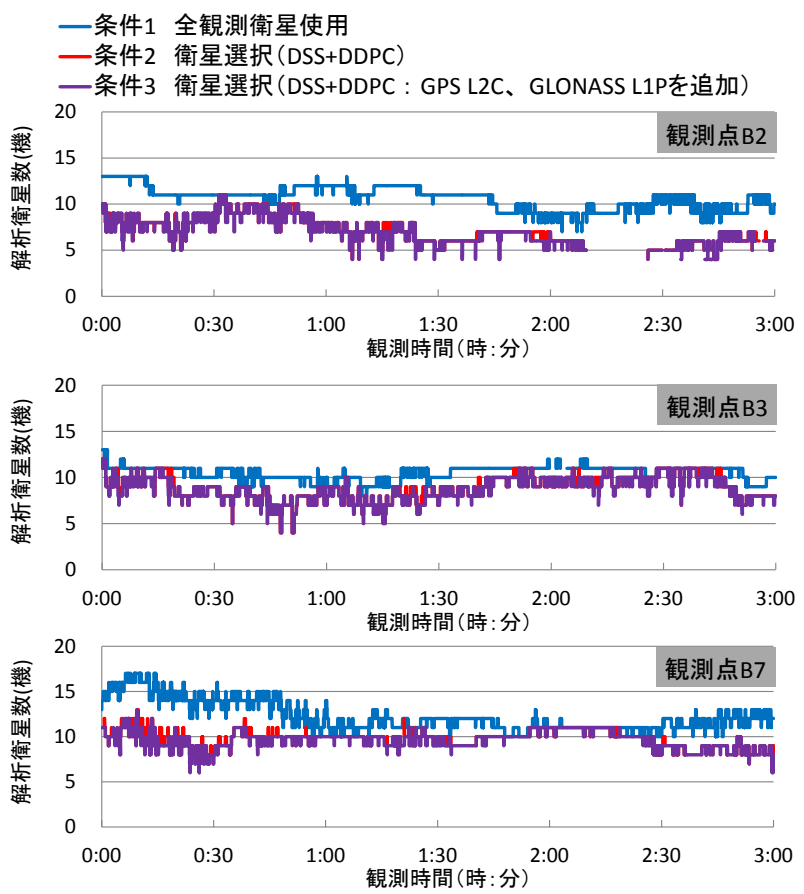

図-17 衛星選択条件別による解析衛星数の推移

点B3でも確認できるが，1:00前後の時間帯など解析に必 要な衛星数を満たしているにも関わらず，Fix解の取得 割合が100\%とならない場合も確認できるため，マルチ パスの影響を受ける衛星を正確に検知できなかつた可能 性が考えられる。なお，観測点B7では，衛星選択条件 が厳しい条件3においても常に6機以上の衛星が確認でき るため, GPS+GLONASSの条件でキネマティック解析に 必要な衛星数を満たし，Fix解の取得割合が増加したも のと考えられる。Fix解の取得割合が100\%とならない時 間帯については，0:00 0:40の時間帯において衛星数が短 

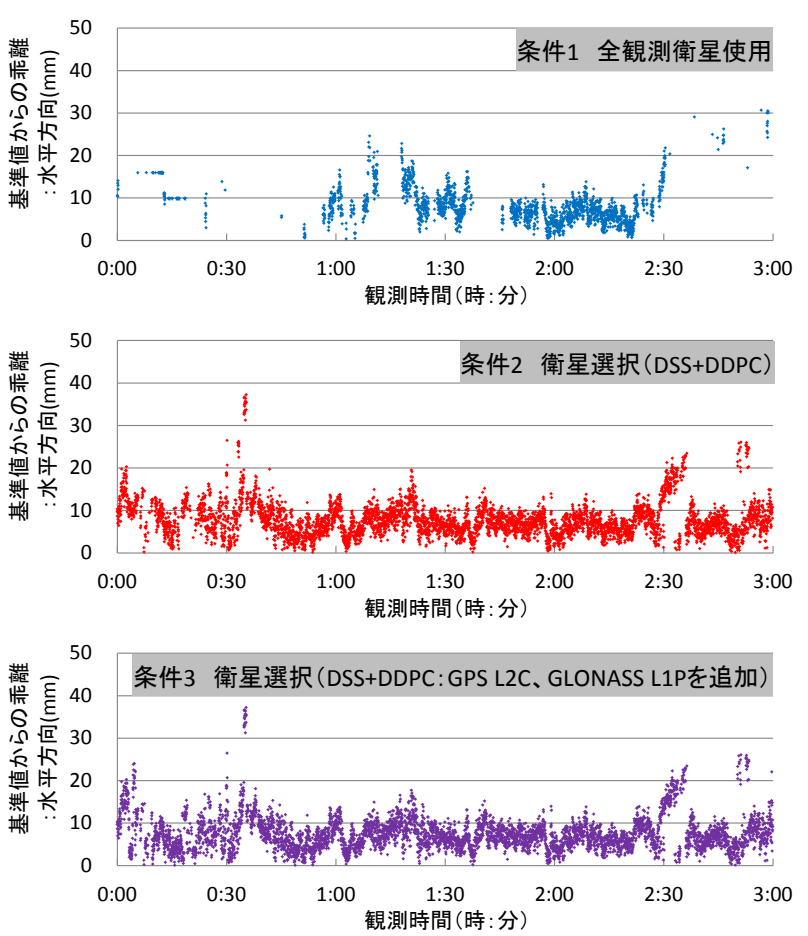

図-18 衛星選択条件別によるFix解の水平方向の乘離

時間で変動していることが確認できるため，観測点B2, B3 と同様にマルチパスの影響を受ける衛星を正確に除 去できなかったものと考えられる.

次に，マルチパスの影響を受ける衛星の除外による測 位精度の改善効果について確認するため, 条件ろにより Fix解の取得割合が向上した観測点B7について, 衛星選 択条件別にの基準座標值からのFix解の乘離を水平方向, 鉛直方向別に算出した．図-18より，水平方向における 基準座標值からのFix解の乘離を衛星選択条件別に比較 すると，衛星選択により Fix解の取得割合が増加した時 間帯については，0:30 0:40，2:40 2:50の時間帯を除き 20mm以内に分布する傾向が確認された。 また，GPSの L2C，GLONASSのL1Pを加えてDSS とDDPCを算出し衛 星選択を行った条件3では，Fix解の取得割合が増加した 0:00 0:40の時間帯において，基準座標值から $10 \mathrm{~mm}$ 以内 に分布するFix解が増加し，測位精度が向上寸る傾向が 確認された．この傾向は，図-19に示守鉛直方向におけ る基準座標值からのFix解の乘離についても確認でき, 測位信号を追加し衛星選択を行った条件では，0:00 0:40 の時間帯において基準座標值から $20 \mathrm{~mm}$ 以内に分布する Fix解の増加が確認された. 図-20より条件2および条件3 における衛星配置を比較すると，樹木・建物により不可 視となる衛星について, 条件3の衛星選択指標を増や寸 ことで除去できる時間帯が長くなっており，条件2より もマルチパスの影響を受ける衛星が除外できていたもの と考えられる. なお，マルチパス検知による衛星選択を 行ったにも関わらず，1:20 1:50の時間帯て鉛直方向にお ける基準座標值からの乘離が大きくなる傾向が確認でき
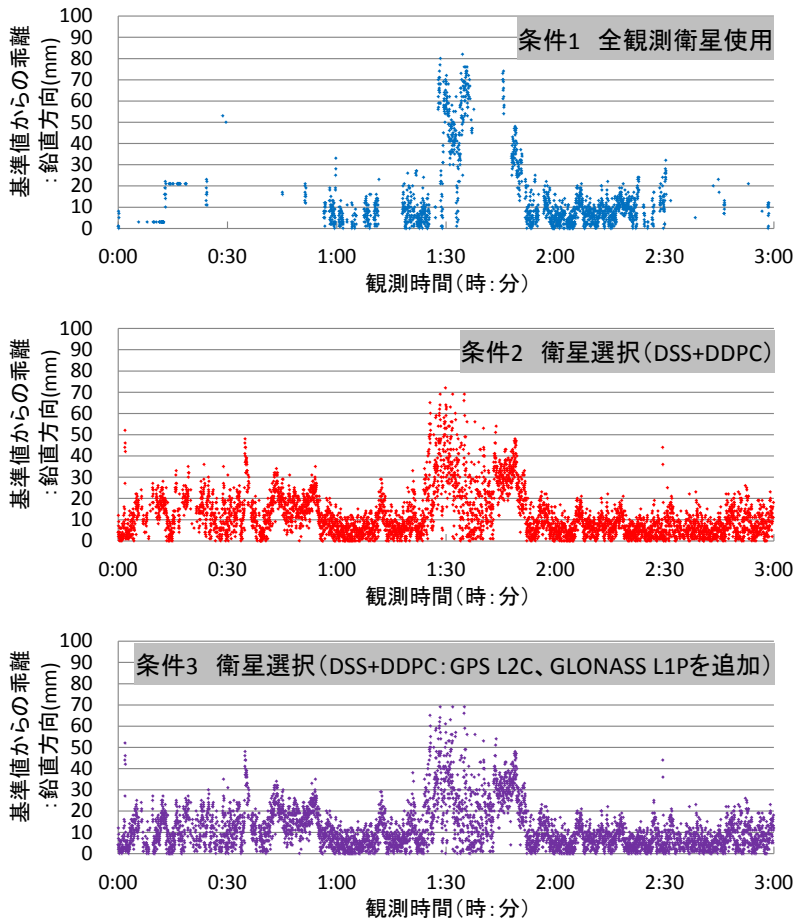

図-19 衛星選択条件別によるFix解の鉛直方向の靟離

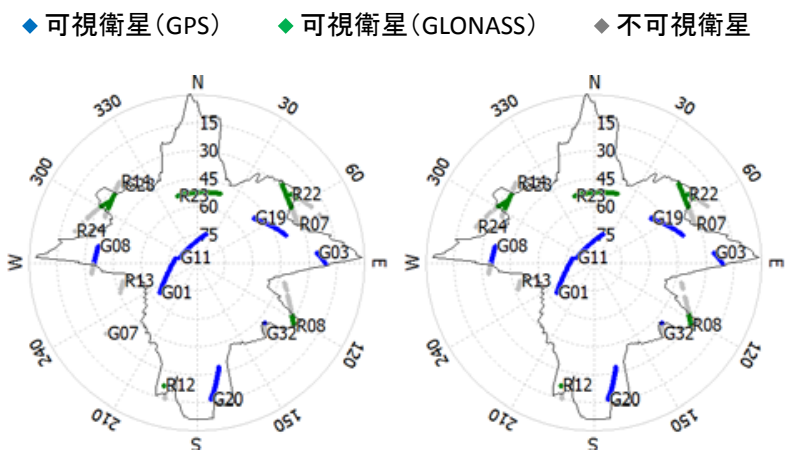

図-20 衛星選択条件別による利用衛星の配置 （観測時間 0:00 0:40 左 : 条件2 右 : 条件3）

るが，衛星配置の鉛直精度劣化度を示すVDOP（Vertical dilution of precision）を確認すると，条件1では1.6 3.1，条 件2では1.9 5.7，条件3では2.2 5.8の間で推移することが 確認された。同時間帯における衛星選択時のVDOP值に ついて大きくなる傾向が見られるため，鉛直方向の衛星 配置条件悪化によるものと考えられる.

これらの検証結果より，複数の測位信号を用いてDSS とDDPCによるマルチパス検知を実施し，解析時の観測 データから使用する衛星を選択することで，Fix解の取 得割合が増加することがわかった．また，衛星選択後に キネマティック解析に必要な衛星数を満たすことで, Fix解の測位精度が水平，鉛直方向に関わらず向上する 傾向が確認された．しかしながら，解析に必要な衛星数 を満たしているにも関わらずFix解が得られない場合， マルチパスの影響を受ける衛星を除去しても基準座標值 からの乘離が大きくなる場合も確認された。これらの要 
因と考えられるVDOPの改善については, QZSSやGalileo 等の利用可能な衛星系の併用によりマルチパスの影響を 受けない 衛星の増加, 鉛直方向の衛星配置条件の改善が 必要であるといえる.

\section{5. 結論}

本研究では，複数測位信号を用いた場合のマルチパス 検知効果について確認するため， DSS とDDPCによる マルチパス検知手法に新たにGPSのL2C, GLONASSの L1P信号を加えて回折波等の影響を受ける衛星電波が検 知可能力検証を行った.

まず，DSS とDDPCによるマルチパス検知指標の検証 では, 各々の測位信号の検証結果より以下の点が明らか になった.

1) 衛星が不可視となり，マルチパスの影響を受ける衛 星電波について，DSSはGPS，GLONASSの測位信号 に関わらず值が小さくなる傾向が確認された。 また, 衛星の可視条件が変化する際のDSSの推移を確認寸る と, GPSのL2P(Y)を除き-5dBHz -6dBHzの範囲内となる ため，閾值を設定することで，マルチパスの影響を 受ける衛星電波の検知は可能であると考えられる.

2) $D D P C$ にいて，可視時の場合は測位信号の組合せ

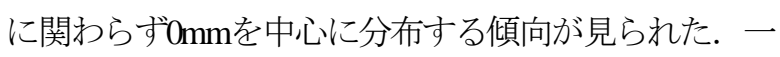
方，不可視時の場合は，正方向に値が分布する傾向 が見られたが，測位信号の組合せによって分布範囲 が異なる傾向が見られた、マルチパスの影響を受け る衛星電波を検知するには，測位信号の組合せに応 じて閾值を設定する必要がある.

次に，検証結果より得られたDSS とDDPCの傾向によ り，マルチパスの影響を受ける衛星の除外を行い，検知 指標が増加した場合の効果について確認を行った結果, 以下の点が明らかになった。

1) マルチパスの影響を受ける衛星電波を除去すること で，全観測衛星を使用した場合よりもFix解の取得割 合が増加し, 高精度測位が可能となる時間帯が増加 することがわかった．また，DSS とDDPC算出時の測 位信号を増やすことで，マルチパスの影響を受ける 衛星電波の検知率が向上し，Fix解の取得割合がさら に増加した.

2) マルチパスの影響を受ける衛星電波を解析に使用し ないことで, 水平方向, 鉛直方向ともに測位精度が 向上することを確認した。一方で，衛星選択により 衛星配置条件が悪化し, 測位精度が低下寸る場合も

\section{確認された.}

以上の結果より，GPSのL2C，GLONASSのL1P信号の ようにDSS とDDPC算出時の測位信号を増や寸ことで, マルチパスの影響を受ける衛星電波の検知率が向上し, 従来よりもFix解の取得割合の増加, 測位精度の向上効 果が得られることがわかった。一方で，衛星選択を行う ことで衛星配置条件が悪化し，Fix解を取得しても鉛直 方向の精度が低下寸る場合も確認された。 この場合, QZSS等の新たな衛星系を測位に併用し，マルチパスの 影響を受けない衛星電波を多く受信できる環境が必要に なると考えられる．また，DDPCについては，今回の検 証では移動平均により值の分布位置を確認し，マルチパ スの影響を受ける衛星検知を行ったが，本手法では，観 測状況が時々刻々と変化する移動体一の適用は困難であ る. $D D P C$ にる算出結果から，瞬時にマルチパスの影 響を受ける衛星を検知寸る手法が必要になると考えられ る.

今後は，QZSS，Galileoの測位信号のほか，GPSのL5波 等のL1，L2波と異なる周波数の衛星電波を使用した場 合についてもマルチパス検知，および衛星選択後の測位 精度について検証を行う予定である.

謝辞 : 本研究は平成24年度科学研究費助成金（基盤研究 C） 23560632 助成を受けた。 ここに記して謝意を申し 上げる.

参考文献

1) 測位航法学会 : GPS/GNSS SYMPOSIUM 2013, pp.40-41, 2013.

2) A. J. Van Dierendonck, P. Fenton and T. Ford : Theory and Perfor-mance of Narrow Correlator Spacing in a GPS Receiver, Navigation, Jonal of the Institute of Navigation, Vol.39, No.3, pp.265-283, Fall 1992.

3）西修二郎：GNSS のすべて，古今晝院，pp.135-137， 2010.

4) Hung Pham Viet, Chien Dao Ngoc, Khang Nguyen Van : A Nonlinear Method of Multipath Mitigation for new GNSS signals, 2014 IEEE Fifth International Conference on Communications and Electronics (ICCE), pp.99-104, 2014.

5) 久保信明, 安田明生 : 定点測位におけるコードマル チパス誤差の削減について, 電子情報通信学会論文 誌 B, Vol.J86-B, No.1, pp.104-112, 2003.

6) Christopher J. Comp, Penina Axelrad : Adaptive SNRBased Carrier Phase Multipath Mitigation Technique, IEEE Transactions on Aerospace and Electronic Systems, vol.34, pp.264-276, 1998.

7) Jizhong Wu, Junqiang Gao, Mingfeng Li, Yongdi Wang : 
Wavelet Transform for GPS Carrier Phase Multipath Mitigation, The 1st International Conference on Information Science and Engineering (ICISE2009), pp.1019-1022, 2009.

8) 池田隆博, 佐田達典 : 静止時の高精度測位における GPS と GLONASS を用いた衛星選択効果に関する研 究，土木学会論文 F3，Vol.69No.2， p.I_98-I_109, 2014.

9) 細矢良雄：電波伝搬ハンドブック，pp.23-24， 1999.

10) Werner Gurtner, Astronomical Institute of the University of Bern, Switzerland and Lou Estey, UNAVCO, Boulder Colorado, USA : RINEX The Receiver Independent Exchange Format Version 3.02, 2013.

11) Pratap Misra and Per Enge : Global Positioning System Signals, Measurements, and Performance Second Edition, Gnga-Jamuna Press, pp.162-164, pp.421-422, 2006.

12）土屋淳，辻宏道 : GNSS 測量の基礎，日本測量協会， pp.182-187, p.221, pp.248-251, pp.260-263, 2008.

(2014. 10. 27 受付)

\section{STUDY ON THE MULTIPATH DETECTION AND PRECISE POSITIONING ACCURACY BY MULTIPLE SATELLITE SIGNALS}

\section{Takahiro IKEDA and Tstsunori SADA}

As for the satellite based positioning system GPS and GLONASS has been used mainly, but QZSS and Galileo has come to be used in recent years. Also, GPS has increased the satellite to send a new positioning signal L2C. Therefore, the satellite positioning can be expected to obtain a good observation data than ever, while it is necessary to remove the satellite signal including the multipath. The authors have verified a method for determining of satellite signal of multipath using the L1C/A and L2P signal strength and the difference of phase change between satellite signal L1C/A and L2P by GPS and GLONASS in previous studies. In this study, newly added L2C signal of GPS and L1P signal of GLONASS, then verified whether detectable satellite signal including a multipath from the actual observed data. As a result, satellite signal affected by multipath can be detected similarly to the conventional positioning signal. In addition, the effect of the increase of multipath detection indicators was confirmed by the percentage of fix solution and positioning accuracy. 